\title{
Three-Dimensional Printing Model as a Tool to Assist in Surgery for Large Mandibular Tumour: a Case Report
}

\author{
Kazuyuki Yusa ${ }^{1}$, Hideyuki Yamanochi ${ }^{2}$, Akira Takagi ${ }^{1}$, Mitsuyoshi Iino ${ }^{1}$ \\ ${ }^{1}$ Department of Dentistry, Oral and Maxillofacial - Plastic and Reconstructive Surgery Faculty of Medicine, Yamagata \\ University, Yamagata, Japan. \\ ${ }^{2}$ Department of Dentistry and Oral Surgery, Shinjo Tokushukai Hospital, Yamagata, Japan.
}

\author{
Corresponding Author: \\ Kazuyuki Yusa \\ Department of Dentistry, Oral and Maxillofacial - Plastic and Reconstructive Surgery Faculty of Medicine \\ Yamagata University \\ 2-2-2 Iida-nishi, 990-9585, Yamagata \\ Japan \\ E-mail: k-yusa@med.id.yamagata-u.ac.jp
}

\section{ABSTRACT}

Objectives: Recently, three-dimensional printing models based on preoperative computed tomography and magnetic resonance imaging images have been widely used in medical fields. This study presents an effective use of the three-dimensional printing model in exploring complex spatial relationship between the tumour and surrounding tissue and in simulation surgery based planning of the operative procedure.

Material and Methods: The patient was a 7-year-old boy with ameloblastic fibro-odontoma. Prior to surgery, a hybrid threedimensional printing model consisting of the jaw bone, the tumour and the inferior alveolar nerve was fabricated. After the simulation surgery based on this model, enucleation of the tumour, leaving tooth 46 intact (Universal Numbering System by ADA) safe, was planned.

Results: Enucleation of the tumour was successfully carried out. One year later, healing was found to be satisfactory both clinically and radiographically.

Conclusions: The study presented an effective application of a novel hybrid three-dimensional printing model composed of hard and soft tissues. Such innovations can bring significant benefits, especially to the field of oncological surgery.

Keywords: mandible; simulation training; three-dimensional printing.

Accepted for publication: 24 June 2017

To cite this article:

Yusa K, Yamanochi H, Takagi A, Iino M.

Three-Dimensional Printing Model as a Tool to Assist in Surgery for Large Mandibular Tumour: a Case Report

J Oral Maxillofac Res 2017;8(2):e4

URL: http://www.ejomr.org/JOMR/archives/2017/2/e4/v8n2e4.pdf

doi: $10.5037 /$ jomr.2017.8204 


\section{INTRODUCTION}

Treatment of large mandibular tumours is relatively common surgery for oral and maxillofacial surgeons. General treatment for these tumours is conservative enucleation or partial mandibulectomy. In cases of some tumours, inadequate surgical removal at the time of initial treatment is one of the risk factors recurrence $[1,2]$ or malignant transformation [3] . Therefore these tumours must be completely enucleated or resected.

Recently, three-dimensional printing models based on preoperative computed tomography (CT) and magnetic resonance imaging (MRI) images have been widely used in medical fields such as orthopaedic surgery, cardiovascular surgery, neurosurgery, and oral and maxillofacial surgery.

This study presents an effective use of the threedimensional printing model in exploring complex spatial relationship between the tumour and surrounding tissue and in simulation surgery based planning of the operative procedure.

\section{CASE DESCRIPTION AND RESULTS}

A 7-year-old boy was referred to our clinic from his family dentist with a chief complaint of swelling in the right buccal region. His past medical history and the findings of a general physical examination were unremarkable. And he had healthy parents and there was no history of systemic diseases. Extraoral examination revealed facial asymmetry with swelling on the right side of mandible. The swelling was asymptomatic and covered with healthy skin of normal colour. Intraorally, the bone in the right molar region showed swelling that was covered

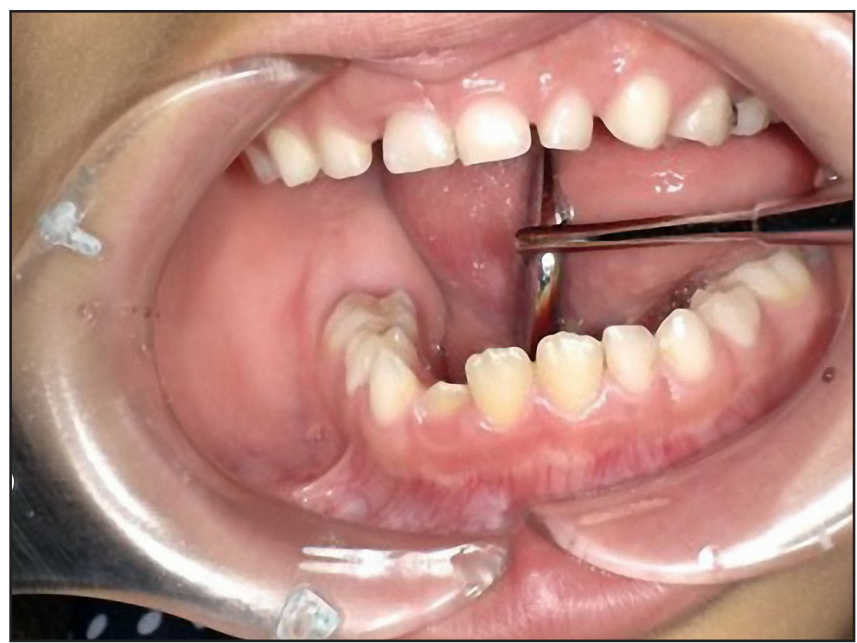

Figure 1. Intraoral photography obtained prior to the surgery. Clinical view showed gingival swelling on the right side of mandible.

by normal mucous membrane (Figure 1). A panoramic radiograph showed a well-defined radiolucent lesion extending from the distal surface of tooth number 46 (Universal Numbering System by ADA) to the whole ramus (Figure 2). Computed tomography (CT) showed that expansion of the mandibular bone and the crown of tooth number 47 were contained within the lesion (Figure 3). Clinically, general examination was unremarkable. Incisional biopsy was performed, and the histological diagnosis was ameloblastic fibroodontoma (AFO).

Prior to surgery, a three-dimensional printing model of the mandible was fabricated. The CT images were transferred to a three-dimensional workstation Zed View (LEXI, Co. Ltd., Tokyo, Japan) and threedimensional volume data for the mandible were obtained by reconstructing the sections. A full sized model was printed by a ZPrinter 450 (Z Corporation, Waltham, Ma, USA) with the use of zp151 powder

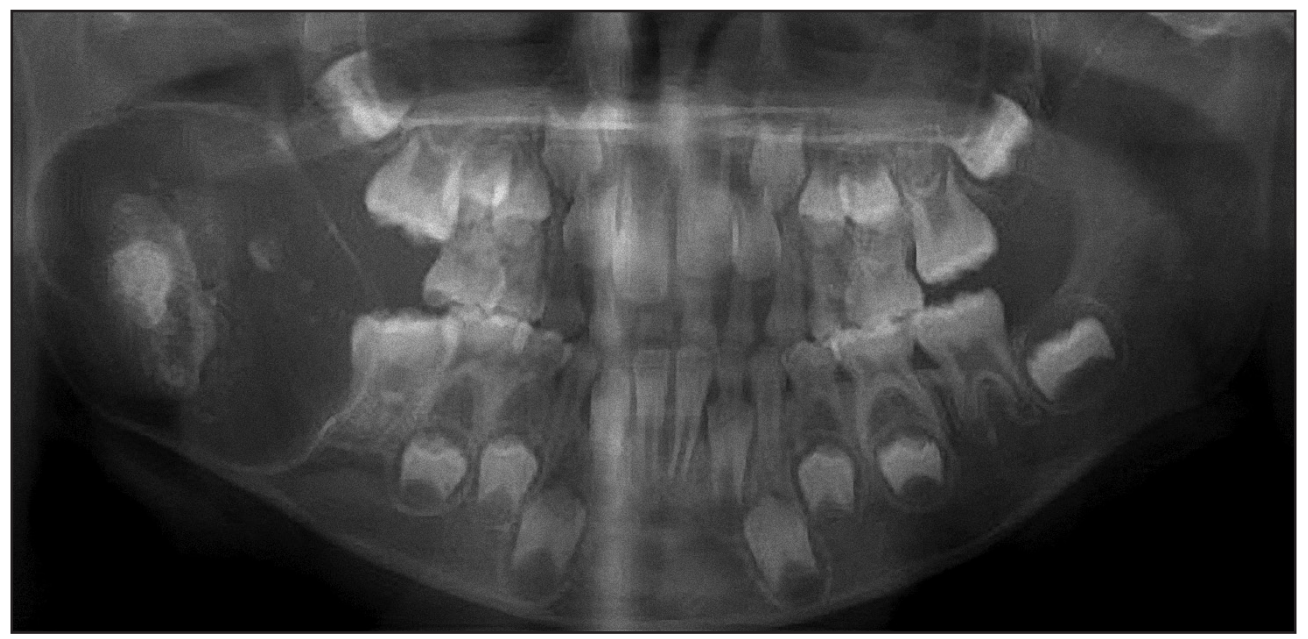

Figure 2. Orthopantomographic radiograph obtained prior to the surgery. The radiography showed a well-defined radiolucent lesion on the right side of mandible. 


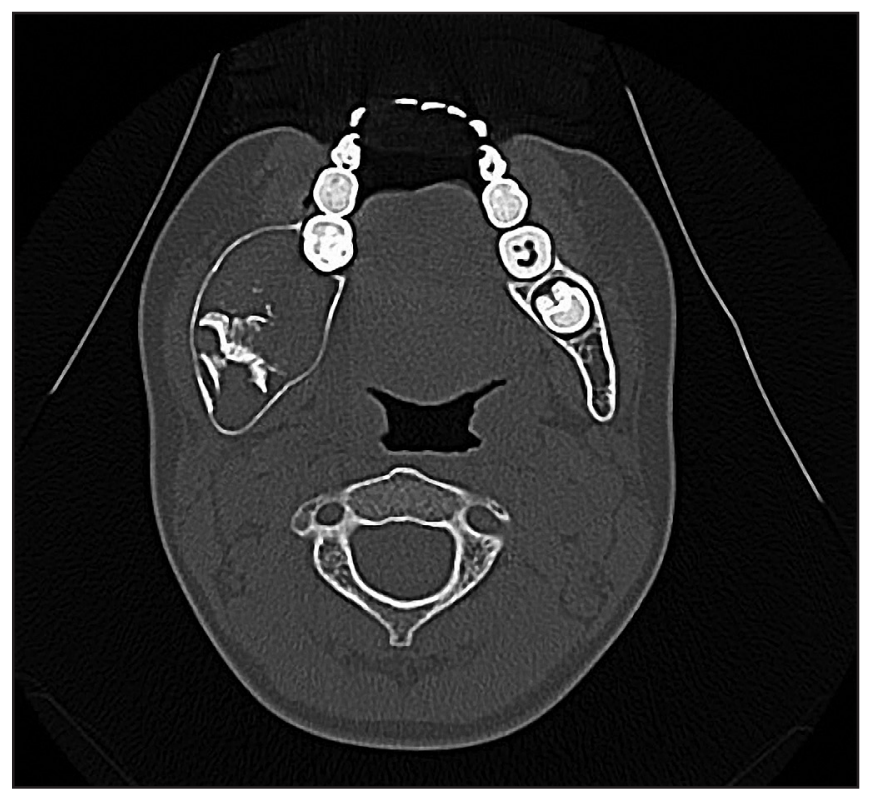

Figure 3. Computed tomography image obtained prior to the surgery. The expansion of the mandibular bone and the crown of tooth number 47 were contained within the lesion.

(3D systems, Rock Hill, SC, USA) for mandibular bone and RTV silicone gum (Shin-Etsu Chemical Co., Ltd., Japan) for the tumour. The calcified tissue in the tumour and the inferior alveolar nerve (IAN) were also fabricated green and yellow, respectively.

The model is shown in Figure 4. The tumour of dimensions $55 \times 40 \times 22 \mathrm{~mm}$ was completely covered with thin cortical bone. The IAN was at the inferior border of the mandible. Cortical bone thickness around the lesion was 0.9 to $1.9 \mathrm{~mm}$ without bone defects at both the lingual side and the buccal side. The border between the tumour and surrounding tissue (bone and IAN) was quite clear. Furthermore, the three-dimensional printing model was used to perform virtual surgery. A bone of size $2.3 \times 2.1 \mathrm{~mm}$, which was covering the surface of the lesion was removed (Figure 5), and enucleation of the lesion was performed. Based on these findings and virtual surgery,

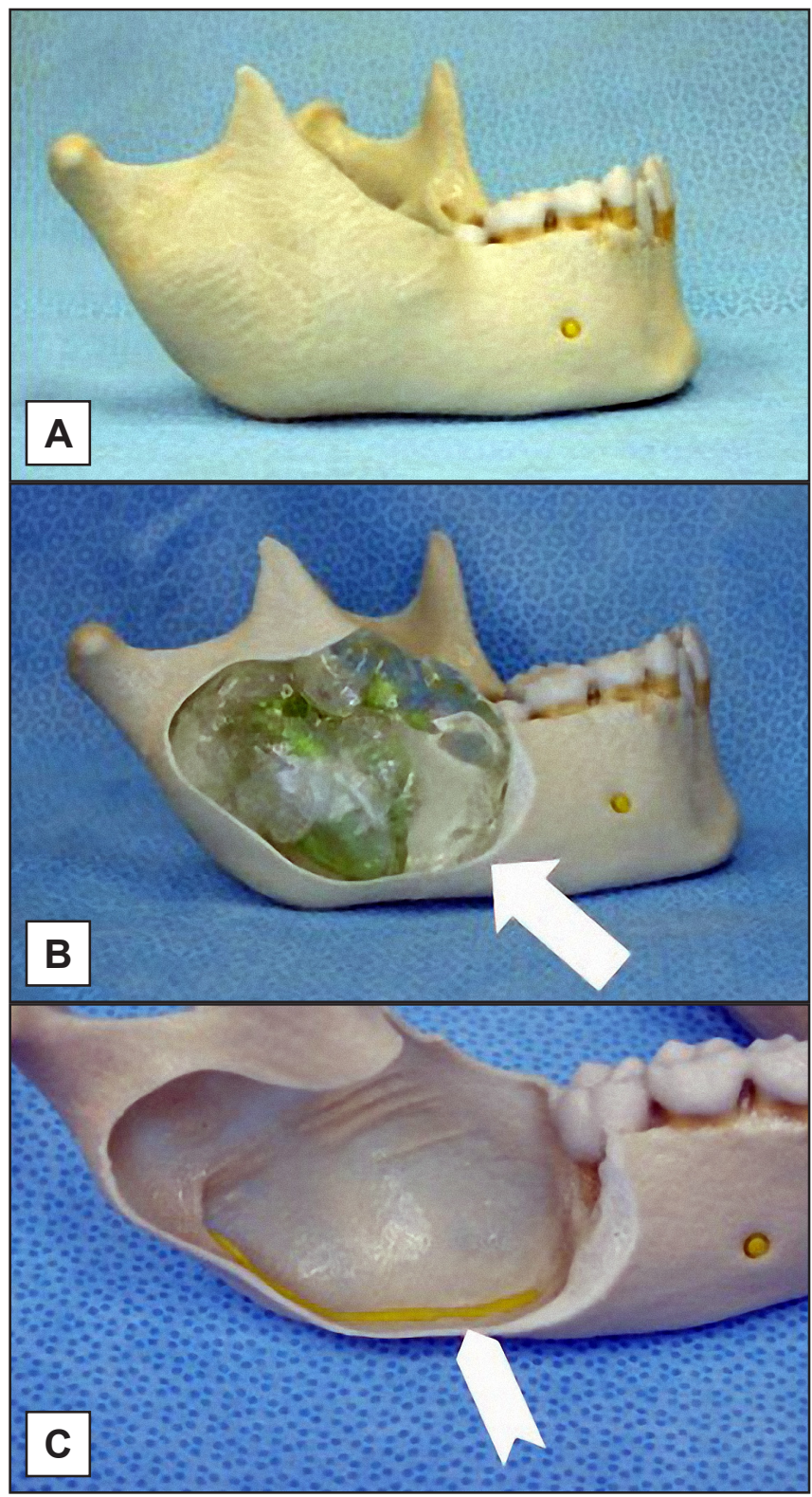

Figure 4. $A=$ Sagittal view of the three-dimensional printing model. $\mathrm{B}=$ After removal of cortical bone of the buccal side. The tumour size was $55 \times 40 \times 22 \mathrm{~mm}$ (arrow).

$\mathrm{C}=$ After removal of the tumour. The inferior alveolar nerve (arrow head) is situated at the inferior border of the mandible.

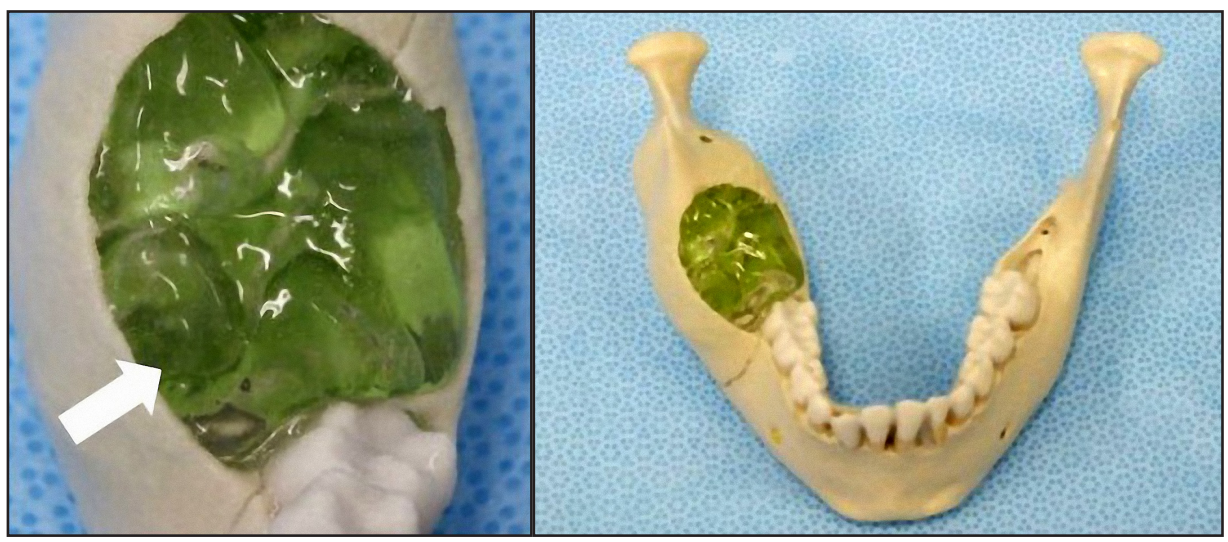

Figure 5. Virtual surgery using three-dimensional printing model, after removal of the cortical bone of size $2.3 \times 2.1 \mathrm{~mm}$ and exposed the tumour (arrow). 


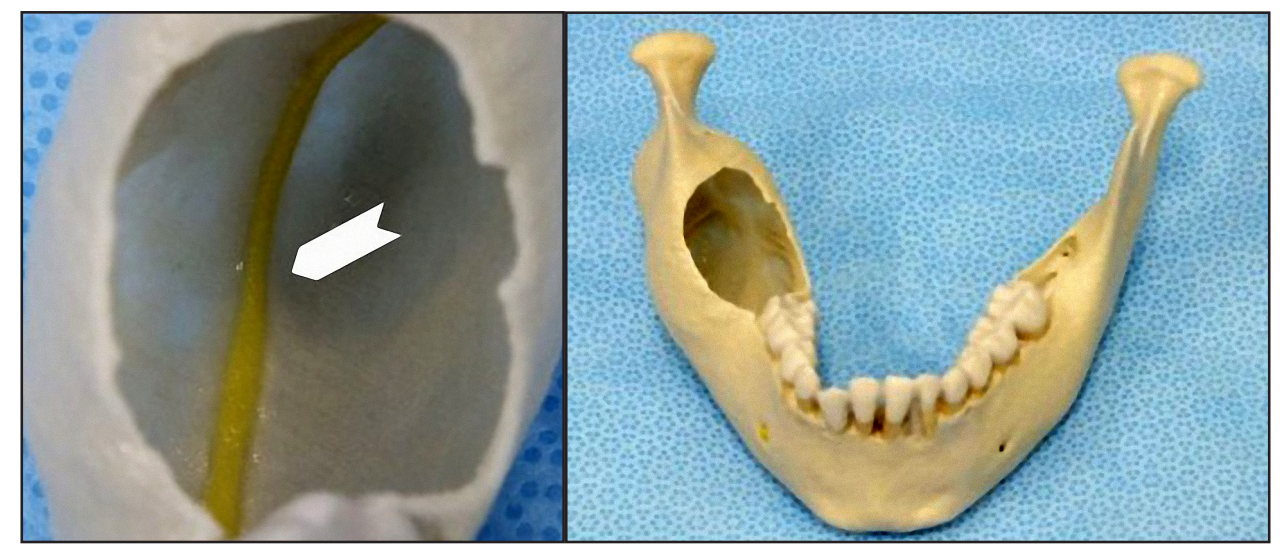

Figure 6. Virtual surgery using three-dimensional printing model, after enucleated the tumour and exposed inferior alveolar nerve (arrow head).

enucleation of the tumour, leaving tooth number 46 safe, was planned (Figure 6).

Enucleation of the lesion was performed under general anaesthesia with intraoral access by a gingival incision. The patient was administered $12 \mathrm{ml}$ of $0.5 \%$ lidocaine with $1: 200,000$ epinephrine around the right molar region infiltration. A full thickness mucoperiosteal flap from the first molar to the edge of the mandibular ramus was reflected. By removing the superficial bone of the tumour (Figure 7), access to the lesion was easily accomplished. The tumour was completely enucleated leaving the surrounding bone, IAN, and tooth number 46 intact (Figure 8). The wound was left open to heal by primary intention. The patient was instructed to rinse twice daily with saline for 1 week. And cefmetazole sodium ( $1 \mathrm{~g} / \mathrm{day})$ was administered intravenously for 3 days after surgery. The patient's postoperative course was unremarkable without complications such as infection, postoperative bleeding, and hypoesthesia of the lower lip.

Histologically, the tumour was composed of odontogenic epithelium tissues (Figure 9A), ameloblast-like cells (Figure 9B), and calcified elements (Figure 9C). These histological examination findings resulted in a final diagnosis of AFO.

A panoramic radiograph of the patient 1 month after surgery showed that the lesion was removed by enucleation (Figure 10). One year later, there was no sign of recurrence, and healing was found to be satisfactory both clinically (Figure 11) and radiographically (Figure 12).

\section{DISCUSSION}

Three-dimensional printing models are being rapidly developed, and these models might be helpful for preoperative planning of surgical procedures in a wide variety of clinical situations [4-7]. The accessibility

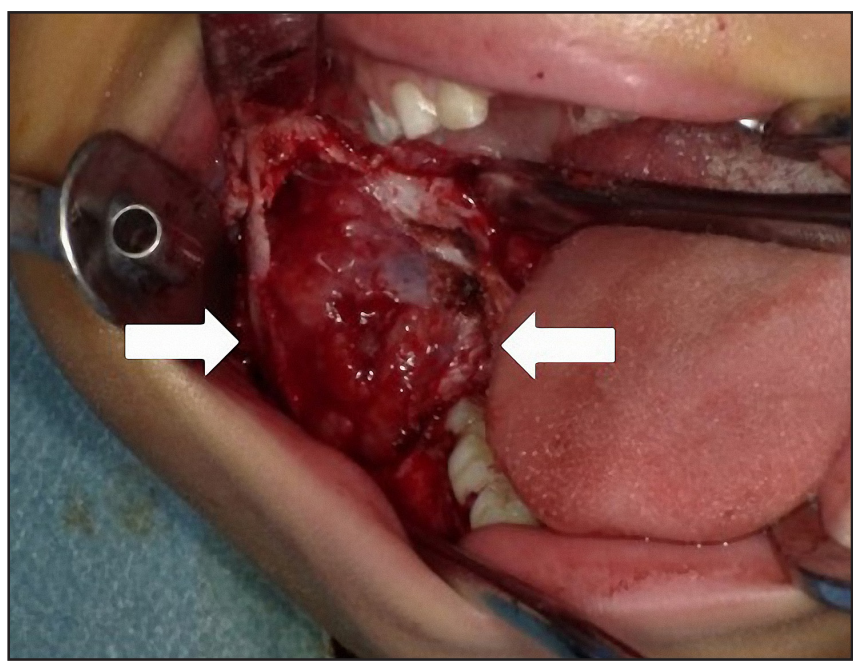

Figure 7. Intraoperative view of the cortical bone and tumour (arrows)

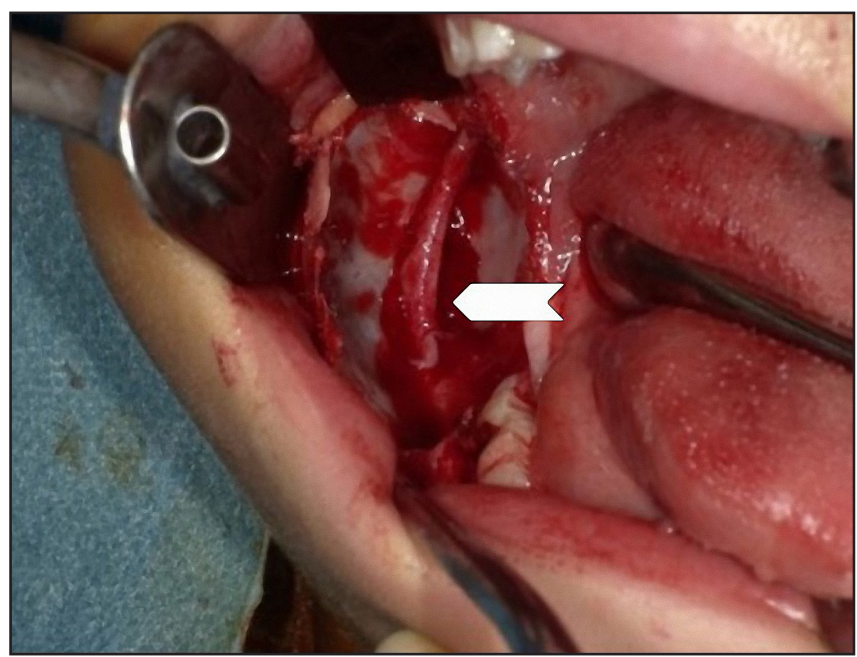

Figure 8. Intraoperative view of the tumour and inferior alveolar nerve (arrow head).

of this technology has spurred its adoption also in oral and maxillofacial surgery, such as oral cancer surgery, orthognathic surgery [8], mandibular reconstruction [9], and dental implantology [10]. 


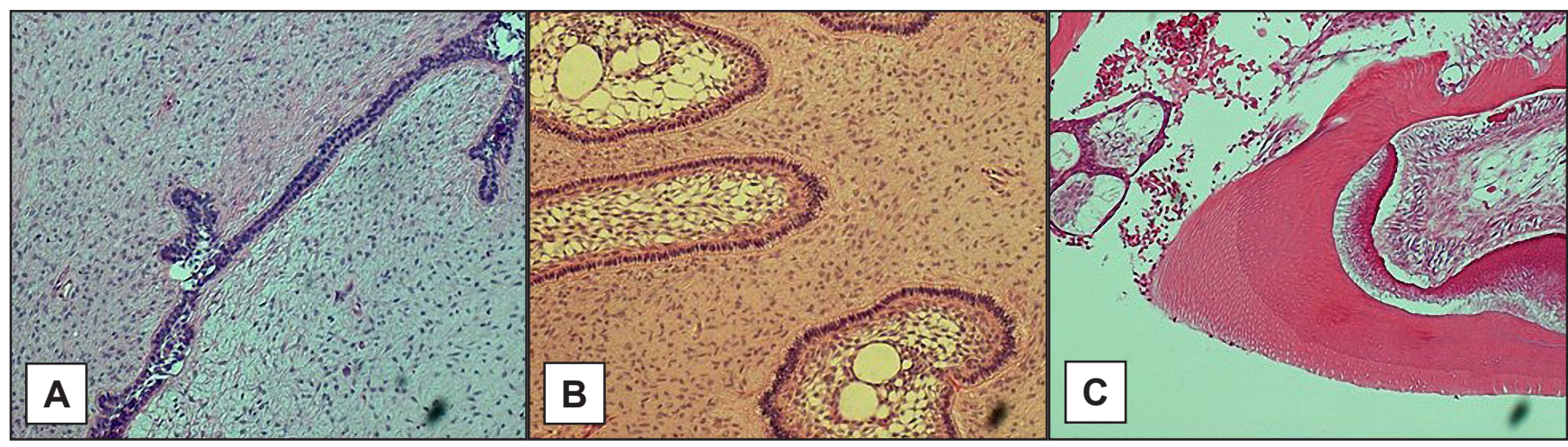

Figure 9. $\mathrm{A}=$ Fibrous stroma containing strands and nests of odontogenic epithelium (haematoxylin-eosin stain, original magnification $\mathrm{x} 100)$.

$\mathrm{B}=$ Differentiated ameloblast-like cells (haematoxylin-eosin stain, original magnification $\mathrm{x} 100$ ).

$\mathrm{C}=$ Calcified elements composed of dentin, enamel matrix, and dental pulp (haematoxylin-eosin stain, original magnification $\mathrm{x} 40)$.

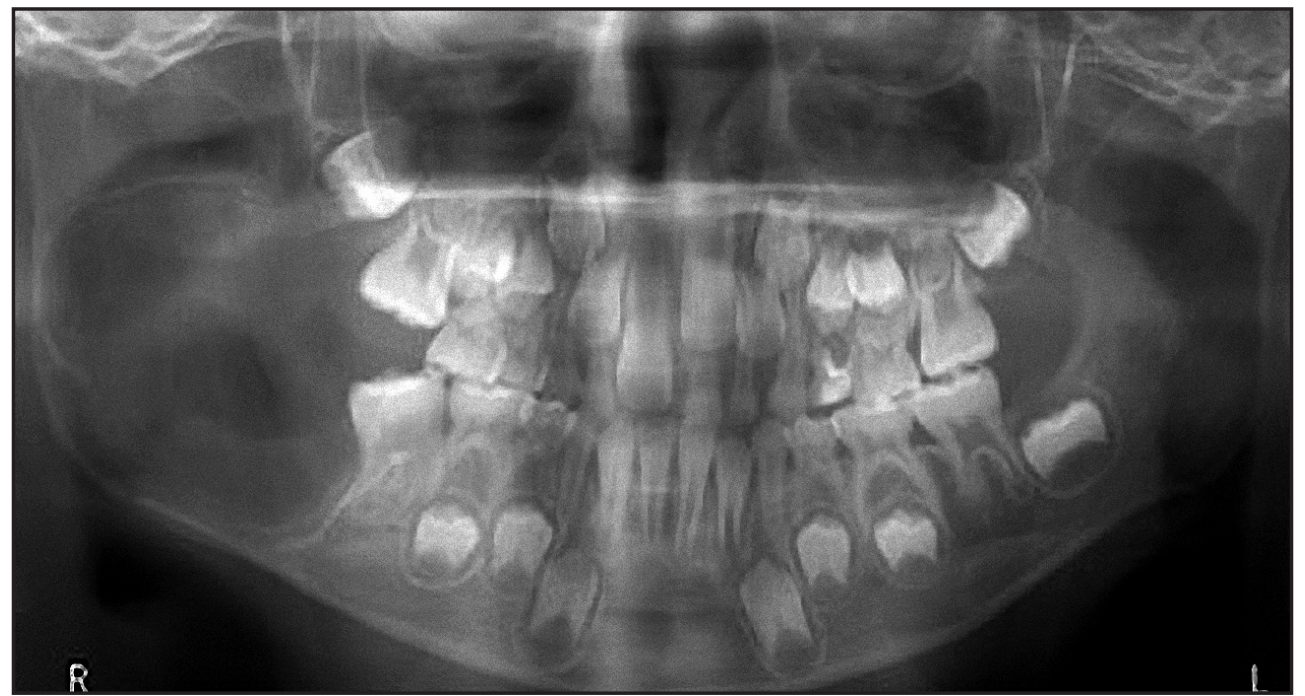

Figure 10. Orthopantomographic radiograph obtained one month after the surgery. The radiograph showed that the lesion was removed by enucleation.

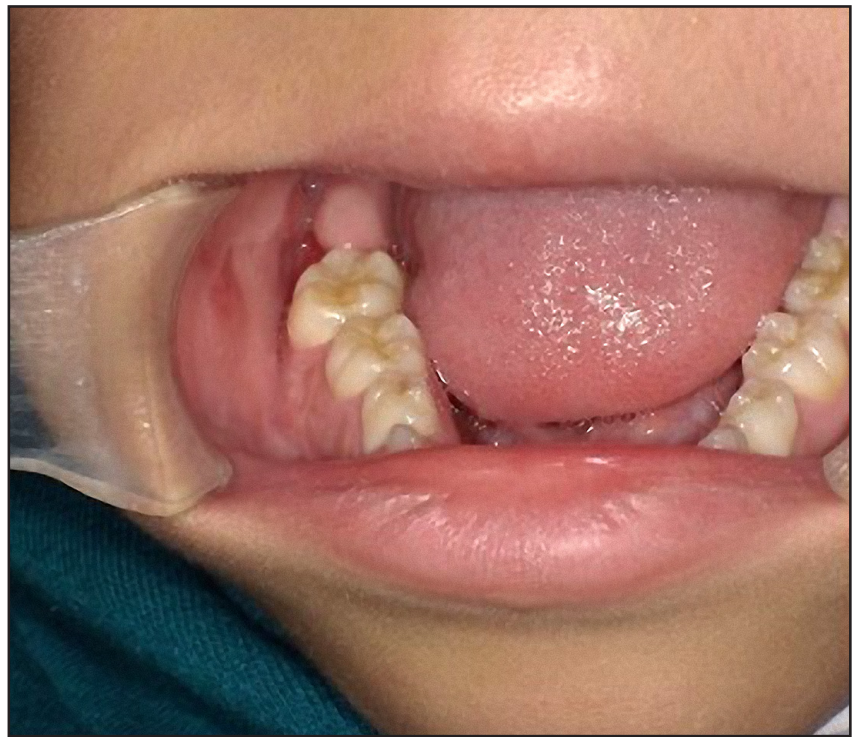

Figure 11. Intraoral photography obtained one year after the surgery. Clinical view indicated gingival healing without swelling.

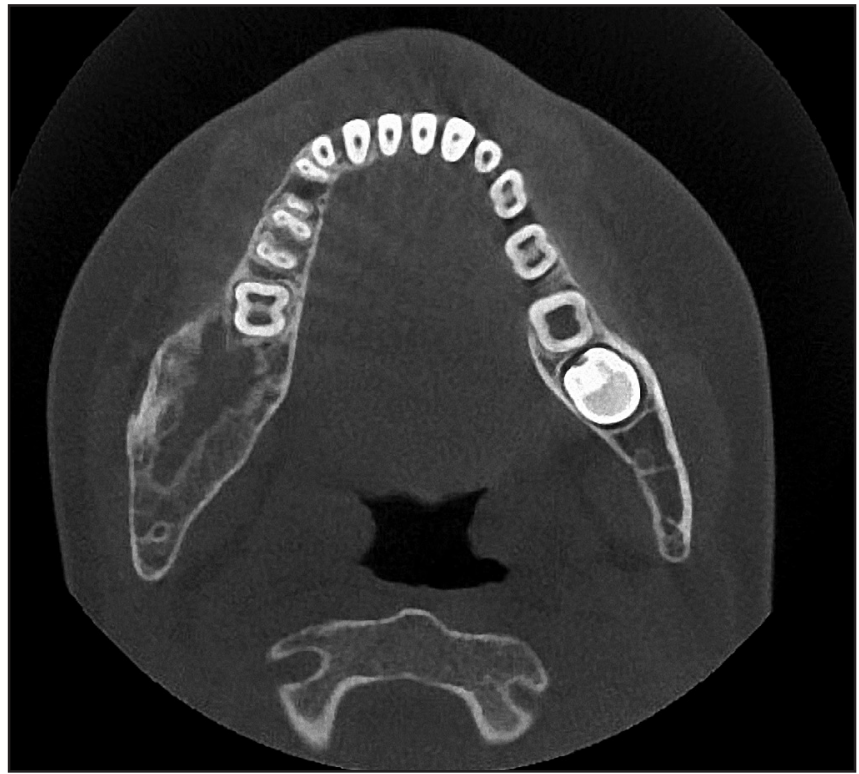

Figure 12. Computed tomography image obtained one year after the surgery. There were no signs of recurrence. 
In these reports, however, three-dimensional printing models that consisted only of bone morphologies were created. In the present case, a hybrid threedimensional printing model consisting of the mandibular jaw bone (white zp151 powder), the tumour (RTV silicone gum), and the IAN was created. To the best of our knowledge, such a hybrid threedimensional printing model has not been reported so far. This model helps us to more easily understand the positional relationships between the tumour and surrounding bone and the IAN.

AFO is a rare benign tumour that has been reported to have a prevalence of $1-3 \%$ among odontogenic tumours. General treatment for AFO is conservative enucleation [11] or partial mandibulectomy [12]. As in the cases of ameloblastoma, inadequate surgical removal at the time of initial treatment is one of the risk factors for AFO recurrence $[\underline{13}, \underline{14}]$. Hence, a residual lesion resulting from inadequate surgical removal must be avoided in cases of AFO. In the present case, there was the risk of a residual lesion after enucleation of the large lesion. The main discussion centered on whether enucleation of the lesion or segmental resection of the mandible would be better.
Based on the analysis of the three-dimensional printing model, because the border of the lesion was well circumscribed, enucleation of the lesion was chosen. As a result, the tumour was successfully enucleated, leaving the IAN and tooth number 46 intact, followed by an unremarkable postoperative course. Thus, this three-dimensional printing model was quite useful for the surgery in this patient.

\section{CONCLUSIONS}

The study presented an effective application of a novel hybrid three-dimensional printing model composed of hard and soft tissues. Such innovations can bring significant benefits, especially to the field of oncological surgery.

\section{ACKNOWLEDGE AND DISCLOSURE STATEMENT}

The authors declare that they have no conflict of interest.

\section{REFERENCES}

1. Bhargava D, Deshpande A, Pogrel MA. Keratocystic odontogenic tumour (KCOT)--a cyst to a tumour. Oral Maxillofac Surg. 2012 Jun;16(2):163-70. [Medline: 22072419] [doi: 10.1007/s10006-011-0302-9]

2. Laborde A, Nicot R, Wojcik T, Ferri J, Raoul G. Ameloblastoma of the jaws: Management and recurrence rate. Eur Ann Otorhinolaryngol Head Neck Dis. 2017 Feb;134(1):7-11. [Medline: 27793625] [doi: 10.1016/j.anorl.2016.09.004]

3. Moro A, Foresta E, Gasparini G, Pelo S, Forcione M, Cristallini EG, Toraldo M, Lorenzo C, Falchi M, Saponaro G. Ameloblastic carcinoma of the maxilla: A case report and an updated review of the literature. Oncol Lett. 2016 Dec;12(6):4339-4350. [Medline: 28105148] [PMC free article: 5228340] [doi: 10.3892/ol.2016.5272]

4. Zeng $\mathrm{C}$, Xiao J, Wu Z, Huang W. Evaluation of three-dimensional printing for internal fixation of unstable pelvic fracture from minimal invasive para-rectus abdominis approach: a preliminary report. Int J Clin Exp Med. 2015 Aug 15;8(8):13039-44. [Medline: 26550226] [PMC free article: 4612911]

5. Sodian R, Weber S, Markert M, Rassoulian D, Kaczmarek I, Lueth TC, Reichart B, Daebritz S. Stereolithographic models for surgical planning in congenital heart surgery. Ann Thorac Surg. 2007 May 83 (5): 1854-1857. [Medline: 17462413] [doi: 10.1016/j.athoracsur.2006.12.004]

6. Sodian R, Schmauss D, Markert M, Weber S, Nikolaou K, Haeberle S, Vogt F, Vicol C, Lueth T, Reichart B, Schmitz C. Three-dimensional printing creates models for surgical planning of aortic valve replacement after previous coronary bypass grafting. Ann Thorac Surg. 2008 Jun;85(6):2105-8. [Medline: 18498831] [doi: 10.1016/j.athoracsur.2007.12.033]

7. Spottiswoode BS, van den Heever DJ, Chang Y, Engelhardt S, Du Plessis S, Nicolls F, Hartzenberg HB, Gretschel A. Preoperative three-dimensional model creation of magnetic resonance brain images as a tool to assist neurosurgical planning. Stereotact Funct Neurosurg. 2013;91(3):162-9. [Medline: 23446024] [doi: 10.1159/000345264]

8. Shqaidef A, Ayoub AF, Khambay BS. How accurate are rapid prototyped (RP) final orthognathic surgical wafers? A pilot study. Br J Oral Maxillofac Surg. 2014 Sep;52(7):609-14. [Medline: 24933576] [doi: 10.1016/j.bjoms.2014.04.010]

9. Cohen A, Laviv A, Berman P, Nashef R, Abu-Tair J. Mandibular reconstruction using stereolithographic 3-dimensional printing modeling technology. Oral Surg Oral Med Oral Pathol Oral Radiol Endod. 2009 Nov;108(5):661-6. [Medline: 19716728] [doi: 10.1016/j.tripleo.2009.05.023]

10. Flügge TV, Nelson K, Schmelzeisen R, Metzger MC. Three-dimensional plotting and printing of an implant drilling guide: simplifying guided implant surgery. J Oral Maxillofac Surg. 2013 Aug;71(8):1340-6. [Medline: 23866950] [doi: 10.1016/j.joms.2013.04.010] 
11. Buchner A, Kaffe I, Vered M. Clinical and radiological profile of ameloblastic fibro-odontoma: an update on an uncommon odontogenic tumor based on a critical analysis of 114 cases. Head Neck Pathol. 2013 Mar;7(1):54-63. [Medline: 23001451] [doi: 10.1007/s12105-012-0397-9]

12. Chen Y, Li TJ, Gao Y, Yu SF. Ameloblastic fibroma and related lesions: a clinicopathologic study with reference to their nature and interrelationship. J Oral Pathol Med. 2005 Nov;34(10):588-95. [Medline: 16202078] [doi: 10.1111/j.1600-0714.2005.00361.x]

13. Friedrich RE, Siegert J, Donath K, Jäkel KT. Recurrent ameloblastic fibro-odontoma in a 10-year-old boy. J Oral Maxillofac Surg. 2001 Nov;59(11):1362-6. [Medline: 11688045] [doi: 10.1053/joms.2001.27537]

14. Frissell CT, Shafer WG. Ameloblastic odontoma; report of a case. Oral Surg Oral Med Oral Pathol. 1953 Sep;6(9): 1129-33. [Medline: 13088009] [doi: 10.1016/0030-4220(53)90224-2]

\section{To cite this article:}

Yusa K, Yamanochi H, Takagi A, Iino M.

Three-Dimensional Printing Model as a Tool to Assist in Surgery for Large Mandibular Tumour: a Case Report

J Oral Maxillofac Res 2017;8(2):e4

URL: http:/www.ejomr.org/JOMR/archives/2017/2/e4/v8n2e4.pdf

doi: $10.5037 /$ jomr.2017.8204

Copyright (C) Yusa K, Yamanochi H, Takagi A, Ino M. Published in the JOURNAL OF ORAL \& MAXILLOFACIAL RESEARCH (http://www.ejomr.org), 30 June 2017.

This is an open-access article, first published in the JOURNAL OF ORAL \& MAXILLOFACIAL RESEARCH, distributed under the terms of the Creative Commons Attribution-Noncommercial-No Derivative Works 3.0 Unported License, which permits unrestricted non-commercial use, distribution, and reproduction in any medium, provided the original work and is properly cited. The copyright, license information and link to the original publication on (http://www.ejomr.org) must be included. 